\title{
Bioassay design and length of time in the laboratory affect intercolonial interactions of the Formosan subterranean termite (Isoptera, Rhinotermitidae)
}

\author{
M. L. Cornelius · W. L. A. Osbrink
}

Received: 21 November 2008/Revised: 13 March 2009/Accepted: 1 April 2009/Published online: 28 April 2009

(C) The Author(s) 2009. This article is published with open access at Springerlink.com

\begin{abstract}
This study examined the effect of diet, experimental design, and length of time in the laboratory on intercolonial agonism among Formosan subterranean termite, Coptotermes formosanus Shiraki, colonies. In pairings of 12 C. formosanus Shiraki colonies collected in an urban forest, there was no significant reduction in survival of termites in 30 out of 59 colony pairs compared to colony controls, but there was $<50 \%$ survival in 18 colony pairs and $<10 \%$ survival in six colony pairs. There was no correlation between the level of aggressive behavior and the laboratory diet of the termites. Effect of bioassay design and length of time in the laboratory was evaluated in three colony pairs where tests were first conducted on the day of field collection, then colony pairs were retested every 7 days. Aggressive behavior decreased over time in both bioassays, but it tended to decrease more rapidly in the Petri dish tests. The rapid loss of agonism in groups of termites kept in the laboratory demonstrates that changes in environmental factors affect intercolonial agonism.
\end{abstract}

Keywords Coptotermes formosanus · Agonism · Diet - Termite survival

This article presents the results of research only. Mention of a commercial or proprietary product does not constitute endorsement or recommendation by the USDA.

M. L. Cornelius $(\bowtie) \cdot$ W. L. A. Osbrink United States Department of Agriculture, Agricultural Research Service,

Southern Regional Research Center,

1100 Robert E. Lee Blvd, New Orleans, LA 70124, USA

e-mail: Mary.Cornelius@ars.usda.gov

\section{Introduction}

The Formosan subterranean termite, Coptotermes formosanus Shiraki, is native to Asia (Bouillon, 1970), but it has been introduced in Hawaii and the southern United States where it has become a devastating pest ( $\mathrm{Su}$ and Tamashiro, 1987). Research on agonistic interactions among colonies of introduced populations of $C$. formosanus has found that some colony pairs are highly agonistic, while other colony pairs display no agonism at all (Su and Haverty, 1991; Shelton and Grace, 1997; Cornelius and Osbrink, 2003; Messenger and $\mathrm{Su}, 2005 \mathrm{a}$ ). Variability in intercolonial aggression was also demonstrated in populations of C. formosanus in China (He et al., 2005, 2006; Pan et al., 2006a, b).

Intercolonial agonism among subterranean termites is highly variable (Thorne and Haverty, 1991; Shelton and Grace, 1996). However, there is no agonistic behavior among colonies of Reticulitermes santonensis Feytaud in France (Dronnet et al., 2006). R. santonensis is now considered to be an introduced population of $R$. flavipes Kollar (Austin et al., 2005). In the United States, R. flavipes generally exhibited low levels of intercolonial agonism (Clément and Bagnères, 1998). However, there was no intercolonial agonism in populations of $R$. flavipes in Massachusetts (Bulmer and Traniello, 2002). Colonies of the European $R$ lucifugus (Rossi) and $R$. banyulensis (Clément) exhibited intercolonial aggression, but there was a great deal of variability among different colonies (Clément and Bagnères, 1998; Uva et al., 2004).

Although many studies have explored possible cues involved in kin recognition by subterranean termites, the reasons for the high levels of variability in intercolonial agonism exhibited by Formosan subterranean termites remain unknown. Intercolonial agonism was not correlated 
with cuticular hydrocarbon profiles (Su and Haverty, 1991) or geographic distance (Su and Haverty, 1991). In Hawaii, there was no correlation between genetic similarities and levels of intercolonial aggression in $C$. formosanus using multilocus DNA fingerprinting (Husseneder and Grace, 2001). However, a positive correlation between genetic distance and levels of agonism has been demonstrated among C. formosanus colonies in Armstrong Park, New Orleans, Louisiana using microsatellite genotyping, indicating that there is a genetic component to colony recognition (Husseneder et al., 2005).

In addition, studies have examined if diet-mediated variations in metabolites, trace dietary minerals, or gland secretions influence intercolonial agonism in C. formosanus. Intercolonial agonism in C.formosanus was not correlated to variation in total protein content of soldiers (He et al., 2005), differences in trace dietary minerals in workers (Pan et al., 2006b), chemical variability of soldier frontal gland secretions (Zhang et al., 2006) or differences in frontal gland, labial glands, or sternal glands (He et al., 2006).

Recently, it has been suggested that increased interactions between neighboring colonies result in higher levels of agonism because colonies may be able to recognize the odor of neighboring colonies after repeated interactions (Messenger and Su, 2005a). The ability to learn to recognize neighboring foragers as non-nestmates would enable neighboring colonies to maintain separate foraging territories.

Diet-induced aggression has been proposed as a factor affecting intercolonial agonism in subterranean termites. Florane et al. (2004) found that the level of aggression displayed by two $C$. formosanus colonies was lower when termites fed on the same diet than when they fed on different diets in the laboratory. Matsuura (2001) proposed that diet-related differences in the composition of symbiotic gut bacteria among colonies of Reticulitermes speratus Kolbe may play a role in nestmate recognition. Changes in the composition of symbiotic gut bacteria have also been shown to induce intercolonial agonism in C. formosanus (Wei et al., 2007).

Bioassay design also affects the level of intercolonial agonism. In some cases, colony pairs that exhibited agonism in foraging arenas did not exhibit any agonism in Petri dish tests (Cornelius and Osbrink, 2003). Messenger and $\mathrm{Su}$ (2005a) also observed differences in the level of agonism displayed by colony pairs depending on bioassay design and suggested that intercolony interactions cannot be adequately evaluated in open air arenas because these tests do not simulate the field situation where termites are encountering each other within their tunneling systems.

In addition, length of time in the laboratory of orphaned groups of foragers may affect the level of agonism between colonies. Intercolonial agonism between groups of
C. formosanus soldiers was much lower when soldiers were tested after 35 days than when they were tested immediately after field collection (He et al., 2005). Laboratory-reared workers of $C$. formosanus displayed reduced levels of intercolonial agonism compared with field-collected workers (Shelton and Grace, 1997). However, Reticulitermes spp. that were kept in the laboratory for 18 months continued to display intercolonial agonism (Getty et al., 2000).

This study examined how laboratory diet, bioassay design, and length of time in the laboratory affected interactions among Formosan subterranean termite colonies from City Park in New Orleans, Louisiana.

\section{Materials and methods}

Termite collections

Termites were collected from field colonies in an urban forest, City Park, New Orleans, LA, where termites were being monitored in over 100 underground traps using cylindrical irrigation valve boxes (NDS Inc, Lindsay, CA) that were buried in the ground and filled with blocks of wood (spruce, Picea sp.). Collections from different traps in the same section of City Park were considered to be separate colonies based on a mark-release-recapture technique using the dye markers Nile Blue A and neutral red (Sigma-Aldrich, Milwaukee, WI) to determine which traps were part of a single, interconnected tunneling system. Any termites from traps containing dyed termites were considered to be part of the same colony as the trap from which the dyed termites were released. Colony identities determined by using mark-release-recapture methods with dyes corresponded with results using multilocus DNA fingerprinting and microsatellite genotyping for colony identification (Husseneder et al., 2003).

\section{Agonism bioassays}

For each bioassay, termites from the same field collections were used. For all bioassays, termites were placed in the testing apparatus using an aspirator, and kept in a dark environmental chamber at $28^{\circ} \mathrm{C}, 97 \% \mathrm{RH}$ for different periods of time. For all Petri dish tests, termites were placed in a $5.5-\mathrm{cm}$ diameter glass Petri dish with a $5.5 \mathrm{~cm}$ diameter moist filter paper on the bottom.

\section{Pairings of colonies from City Park}

Tests were conducted within 7 days of field collection of termites. For each replicate, ten workers from each of two colonies were placed in a Petri dish. There were 12 
colonies combined in 59 colony pairs, with 10 replicates for each pair. There were ten control replicates for each colony. For controls, 20 workers from the same colony were placed in a Petri dish. After $24 \mathrm{~h}$, the number of termites surviving in each replicate was determined.

\section{Effect of laboratory diet on intercolonial interactions}

The following colony pairs were tested: BK, DF, FK, and BD. Two types of bioassays were used: 24-H Petri dish tests and $48-\mathrm{H}$ vial tests. Each bioassay was conducted using field-collected termites, then repeated using termites fed one of two food sources for 60 days. Tests with field-collected termites from different colonies were conducted within 3 days of field collection. For the assays using laboratoryfed termites, groups of termites from field collections were separated from the wood blocks in which they were collected and placed on clean wood blocks: $5 \mathrm{~g}$ (about 1,500 termites) of workers and soldiers from each colony were placed in plastic containers $(34 \mathrm{~cm} \times 15 \mathrm{~cm} \times 10 \mathrm{~cm})$ with clean moist sand and either spruce, Picea sp., blocks or red oak, Quercus rubra L., blocks. Groups of workers and soldiers from each colony were placed in containers with the same proportion of worker to soldiers as existed in the field collections.

\section{4-H Petri dish tests}

For each test, ten workers from each of two colonies were placed in a dish. After $24 \mathrm{~h}$, the number of termites surviving in each replicate was determined. There were ten replicates for each of the four colony pairs.

After 60 days, 24-H Petri dish tests were repeated for the four colony pairings and for controls that had been fed on the following diet combinations: spruce versus spruce; red oak versus red oak; colony 1 on spruce versus colony 2 on red oak; colony 1 on red oak versus colony 2 on spruce. For controls, all termites in a replicate came from the same colony-either 10 termites fed each of the two diets or 20 termites fed a single diet. For each colony, there were ten replicates per diet combination.

\section{8- $H$ vial tests}

Messenger and $\mathrm{Su}$ (2005a) suggested that intercolonial interactions cannot be adequately evaluated in open air arenas because these tests do not simulate the field situation where termites are encountering each other within their tunneling systems. Therefore, bioassays were conducted where termites needed to tunnel through a sand-filled tube in order to encounter each other.

The testing apparatus consisted of two plastic snap vials $(5 \mathrm{~cm}$ height $\times 2 \mathrm{~cm}$ diam) connected by a $4 \mathrm{~cm}$ piece of
PVC tubing (ID $4.8 \mathrm{~mm}$, OD $7.9 \mathrm{~mm}$, Wall $0.79 \mathrm{~mm}$ ) (Nalgene, Rochester, NY) through holes located on the sides of the vials. Both vials were filled with sand so that the sand was level with the bottom of the entrance to the tubing to prevent sand from blocking the entrance. The tubing was also filled with sand. Sand in the vials and tubing was moistened with distilled water. The tubing was inserted into the holes in the vials and sealed with hot glue applied with a glue gun. In each vial, a 1-cm diameter filter paper disk was placed on top of the sand as a food source. For each replicate, 20 workers and 3 soldiers from each colony were placed in 1 of the 2 vials. There were five replicates for each colony pair. After $48 \mathrm{~h}$, the number of surviving termites was determined.

In order to compare termite survival in 24-H Petri dish tests with survival in $48-\mathrm{H}$ vial tests, the following colony pairs were tested in $48-\mathrm{H}$ vial tests within 3 days of being collected in the field: BK, FK, and BD.

After 60 days, $48-\mathrm{H}$ vial tests were repeated for three colony pairings on the following diet combinations: spruce versus spruce; red oak versus red oak; colony 1 on spruce versus colony 2 on red oak; colony 1 on red oak versus colony 2 on spruce. There were three control replicates for each colony for each diet combination: spruce versus spruce; red oak versus red oak; spruce versus red oak.

Effect of bioassay design and length of time in the laboratory on intercolonial interactions

In order to evaluate the rate of decline of aggressive behavior in the laboratory and determine if differences in bioassay design had an effect on the rate of decline, colony pairs were collected in the field and paired in both $72-\mathrm{H}$ Petri dish tests and $72-\mathrm{H}$ y-tube tests. Y-tube tests were designed to better simulate the field situation where termites encounter each other within their tunneling system by increasing the length of sand-filled tubing and making it more likely that termites would encounter each other at the intersection of the tunnels constructed by each colony than in the vial tests.

Pairs were first tested on the day of field collection, then were retested every 7 days until there was no evidence of aggressive behavior or until there were not enough termites left to conduct additional tests. For these tests, termites and the wood blocks from which the termites were collected in the field were transferred directly to plastic containers $(34 \mathrm{~cm} \times 15 \mathrm{~cm} \times 10 \mathrm{~cm})$ with moist sand. Because Pan et al. (2006a) had proposed that soil microorganisms or volatiles influenced agonism among Formosan subterranean termite colonies, soil obtained from the bottom of the trap from which the termites were collected was also added to the container. Additional wood blocks were added to 
each container to make sure that termites had plenty of food. Termites were kept in the laboratory at ambient conditions.

There were three colony pairs tested: BD, GM, and KL. In all three colony pairs, both colonies were collected from the same section of City Park. Colonies B and D are located $<50 \mathrm{~m}$ apart and share a contiguous border. Colonies $\mathrm{G}$ and $\mathrm{M}$ were collected from traps located within $100 \mathrm{~m}$. Colonies $\mathrm{K}$ and $\mathrm{L}$ were collected from traps located $>100 \mathrm{~m}$ apart. When termites from $\mathrm{K}$ and $\mathrm{L}$ were tested 28 days after collection, there were no soldiers remaining in the box of termites from Colony $\mathrm{K}$. Therefore, the remaining tests with $\mathrm{KL}$ were conducted using only workers of each colony.

\section{2-H Petri dish tests}

These bioassays were conducted using 20 workers and two soldiers in each replicate and 5 replicates of each colony pair at each time period. After $72 \mathrm{~h}$, the number of termites surviving in each replicate was determined.

\section{2-H y-tube tests}

There were five replicates of each colony pair at each time period. The testing apparatus consisted of three plastic snap cap vials $(5 \mathrm{~cm}$ height $\times 2 \mathrm{~cm}$ diam) connected to a y-tube by a $5 \mathrm{~cm}$ piece of PVC tubing (ID $4.8 \mathrm{~mm}$, OD $7.9 \mathrm{~mm}$, Wall $0.79 \mathrm{~mm}$ ) (Nalgene, Rochester, NY) inserted through a hole in the side of each vial and sealed with hot glue applied with a glue gun. Each vial was filled with sand so that the sand was level with the bottom of the entrance to the tubing to prevent sand from blocking the entrance. For each vial, the ends of the PVC tubing were connected to a plastic y-tube $(6 \mathrm{~cm}$ in length, $1 \mathrm{~cm}$ diam) (VWR Scientific, West Chester, PA). The arms and stem of the y-tube were filled with sand and the sand was moistened with distilled water. In each vial, a small block of spruce (Picea sp.) wood $(2 \mathrm{~cm} \times 1.5 \mathrm{~cm} \times 0.5 \mathrm{~cm})$, moistened with distilled water, was placed on top of the sand. Forty workers and five soldiers from each colony were placed in the two vials connected to the arms of the y-tube, one colony in each vial. Termites were not placed in the vials connected to the stem of the y-tube so that there was an additional site with a food source that could only be reached by the construction of tunnels from the release sites of the two colonies. After $72 \mathrm{~h}$, the number of termites surviving in each replicate was determined.

\section{Statistical analyses}

Survival of termites in the 59 colony pairs and 12 controls were compared using a binomial distribution where significant differences were based on 95\% confidence intervals.
For experiments on the effect of diet, bioassay design, and length of time in the laboratory, data on termite survival were analyzed by transforming the proportion of survivors by the arcsine of the square root. The effect of diet on intracolonial interactions was analyzed by comparing survival in the control replicates for each colony using a two-way ANOVA with diet (spruce/spruce, red oak/red oak, spruce/red oak) and colony as the independent variables. The effect of diet on intercolonial interactions was analyzed by comparing survival of termites in the colony pair replicates using a one-way ANOVA with diet (field, spruce/spruce, red oak/red oak, spruce/red oak) as the independent variable. Means were separated using Tukey HSD test.

The effect of experimental design on the rate of decline in aggressive behavior of termites in each colony pair was analyzed by comparing each bioassay at each time period using a two-way ANOVA where bioassay design and time period were independent variables. If there was a significant interaction between bioassay design and time period, a one-way ANOVA was performed for each time period where bioassay design was the independent variable and a one-way ANOVA was performed for each bioassay design where time period was the independent variable. Means were separated using Tukey HSD test.

\section{Results}

Pairings of colonies from City Park

None of the colonies exhibited less than $93 \%$ survival in controls (Table 1). Survival in 30 colony pairs was not significantly different than survival in controls (binomial distribution: $P<0.05$ ). Survival was $<50 \%$ in 18 colony pairs and $<10 \%$ in six colony pairs (Table 1 ). Colony B had the most interactions with other colonies (nine colony pairings) that resulted in significant reductions in survival. In addition, four of the six colony pairs resulting in $<10 \%$ survival involved Colony B (Table 1). In contrast, there was only a significant reduction in survival of termites in two colony pairs involving Colony $\mathbf{J}$ (Table 1 ).

\section{Effect of laboratory diet on intercolonial interactions}

In 24-H Petri dish tests, mean percent survival was $>96 \%$ in all of the control diet combinations and there were no significant differences in the survival of termites from the different colonies $(F=0.70 ; d f=3,108 ; P=0.55)$ or from the three diet combinations tested $(F=0.96 ; d f=2$, $108 ; P=0.96)$. There was no significant interaction between the variables colony and $\operatorname{diet}(F=0.28 ; d f=6$, 


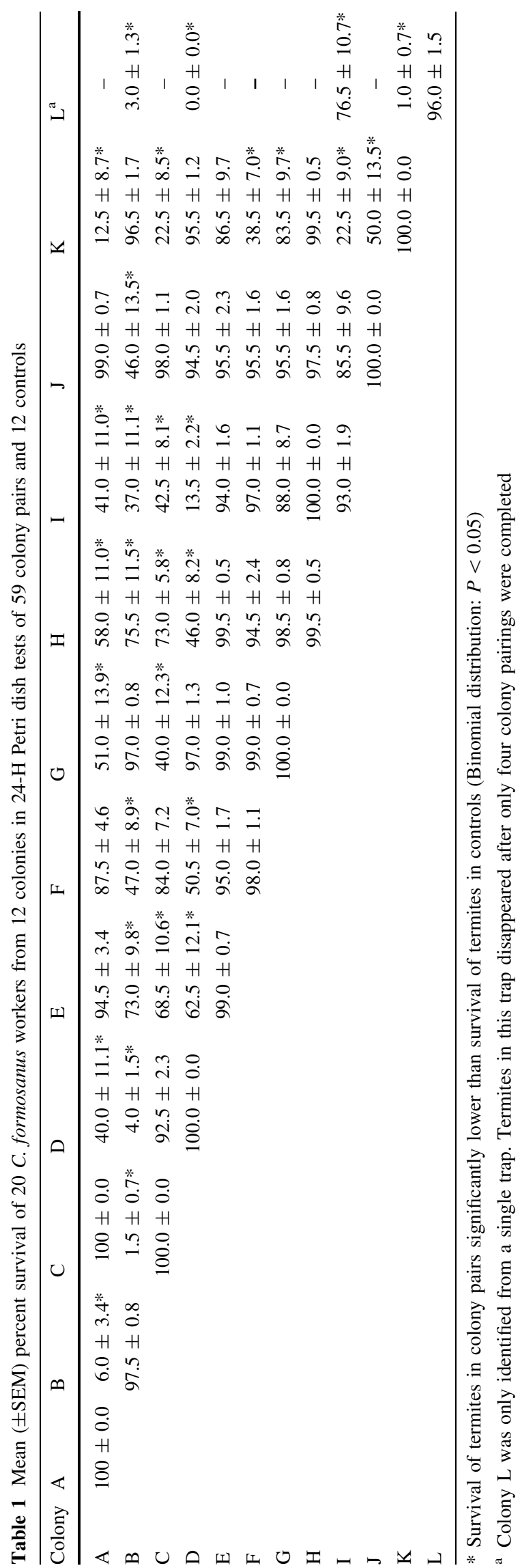

108; $P=0.95)$. In $48-\mathrm{H}$ vial tests, mean percent survival was $>86 \%$ in all of the control diet combinations and there were no significant differences in the survival of termites from any of the colonies $(F=1.0 ; d f=3,24 ; P=0.38)$ or among the three diet combinations tested $(F=1.2$; $d f=2,24 ; P=0.33)$. There was no significant interaction between the variables colony and diet $(F=0.75 ; d f=6$, 24; $P=0.60)$.

For Colony Pair BK, there were no significant differences in the survival of termites in pairings of fieldcollected termites or among the four diet combinations for groups fed on laboratory diets for 60 days in either $24-\mathrm{H}$ Petri dish tests $(F=0.29 ; d f=4,45 ; P=0.88)$ or $48-\mathrm{H}$ vial tests $(F=0.37 ; d f=4,20 ; 0.83)$ (Fig. 1a).

For Colony Pair DF, there were significant differences in survival of termites in the different pairings of groups kept in the laboratory for 60 days in 24-H Petri dish tests $(F=6.27 ; d f=4,45 ; P=0.001)$. However, survival of termites was significantly greater than survival of fieldcollected termites when both colonies ( $D$ and F) fed on red oak, and when the two colonies fed on different diets, D on red oak/F on spruce $(P<0.05$; Tukey HSD Test $)$ (Fig. 1b).

For Colony Pair FK, survival was significantly greater in all diet combinations when termites were kept in the laboratory for 60 days compared to field-collected termites in both 24-H Petri dish tests $(F=76.9 ; \quad d f=4,45$; $P<0.0001)$ and $48-\mathrm{H}$ vial tests $(F=10.4 ; d f=4,20$; $P<0.0001$ ) (Fig. 1c).

For Colony Pair BD, survival was significantly greater in all diet combinations when termites were kept in the laboratory for 60 days compared to field-collected termites in 24-H Petri dish tests $(F=60.5 ; d f=4, \quad 45$; $P<0.0001)$, but there were no significant differences in survival between the pairings of field-collected termites and pairings of termites kept on any of the diet combinations in $48-\mathrm{H}$ vial tests $(F=1.5 ; d f=4,20 ; P=0.23)$ (Fig. 1d).

Effect of bioassay design and length of time in laboratory on intercolonial interactions

In Colony Pair BD, there were significant differences in the survival of termites in 72-H Petri dish tests at the different time periods $(F=8.01 ; d f=7,32 ; P<0.0001)$. Survival was significantly lower at Days 0,7 , and 14 than at Days 42 and 49. Survival was also significantly lower at Days 21 and 28 than at Day 49. There were no significant differences in the survival of termites in $72-\mathrm{H}$ y-tube tests at the different time periods $(F=1.2 ; d f=8,36 ; P=0.32)$ (Fig. 2a). In 72-H Petri dish tests, survival steadily increased over time, whereas survival in 72-H y-tube tests was variable. However, after 49 days, there was $87 \%$ 

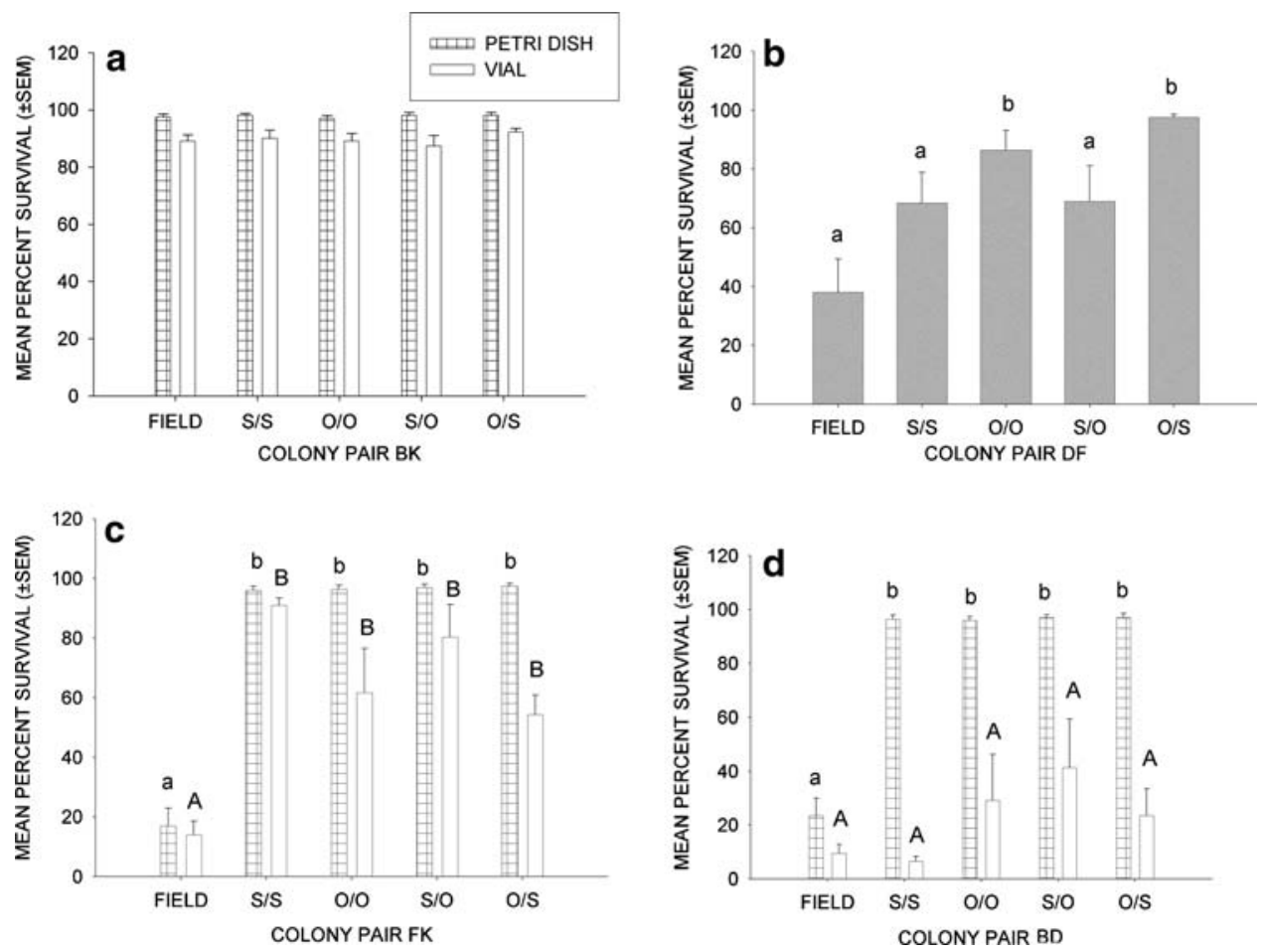

Fig. 1 Mean $( \pm$ SEM) percent survival of termites in colony pairs when tested within 3 days of field collection and after 60 days on different diet combinations in $24-\mathrm{H}$ Petri dish tests and $48-\mathrm{H}$ vial tests. Field field-collected; $S / S$ both colonies fed on spruce; $O / O$ both colonies fed on red oak; S/O colony 1 fed on spruce, colony 2 fed on red

average survival in Petri dish tests, while there was only $49 \%$ average survival in y-tube tests. Although there was $<60 \%$ average survival in y-tube tests after 56 days, there were not enough termites in the collection from Colony D to conduct another test.

In Colony Pair BD, termite survival was lower in $72-\mathrm{H}$ Petri dish tests than in 72-H y-tube tests $(F=11.2 ; d f=1$, $64 ; P=0.001)$. There was a significant interaction between bioassay design and time period $(F=3.54$; $d f=7,64 ; P=0.006$ ). Therefore, survival of termites was compared in the two bioassays for each time period using a one-way ANOVA. At Days 0, 14, and 28, survival of termites in 72-H y-tube tests was significantly greater than in 72-H Petri dish tests (Day 0: $F=15.3 ; d f=1,8$; $P=0.005$; Day $14: F=5.96 ; d f=1,8 ; P=0.04$; Day 28: $F=112.5 ; d f=1,8 ; P<0.0001)$. There was no significant difference in survival of termites in the two bioassays at Days 7, 21, 35, 42, and 49 (Day 7: $F=0.97$; $d f=1,8 ; \quad P=0.35 ; \quad$ Day $21: \quad F=2.4 ; \quad d f=1, \quad 8$; $P=0.16$ 1; Day 35: $F=1.5 ; d f=1,8 ; P=0.25$; Day 42: $F=0.80 ; d f=1,8 ; P=0.39$; Day $49: F=3.190$; $d f=1,8 ; P=0.11$.

In Colony Pair GM, survival of termites in $72-\mathrm{H}$ Petri dish tests was significantly lower at Day 0 than at Days 7 and $14(F=11.53 ; d f=2,12 ; P=0.002)$. Survival of

oak; $O / S$ colony 1 fed on red oak, colony 2 fed on spruce. Percent survival of termites in bars with the same lowercase letters was not significantly different in 24-H Petri dish tests. Percent survival of termites in bars with the same uppercase letters was not significantly different in 48-H vial tests. a BK, b DF (Petri dish test only), c FK, d BD

termites in 72-H y-tube tests was not significantly different at the different time periods $(F=2.76 ; d f=2,12$; $P=0.10$ ) (Fig. 2b).

There was a significant interaction between bioassay design and time period $(F=5.27 ; d f=2,24 ; P=0.01)$. Therefore, survival of termites was compared in the two bioassays for each time period using a one-way ANOVA. There was no significant difference in the survival of termites in the two bioassays at Day $0(F=1.8 ; d f=1,8$; $P=0.22$ ). At Day 7 , survival was significantly greater in Petri dish bioassays than in y-tube bioassays $(F=10.56$; $d f=1,8 ; P=0.01)$. At Day 7 , aggressive behavior had completely disappeared in Petri dish bioassays, but fighting was observed in one replicate of the y-tube tests where survival was only $20 \%$. At Day 14 , there was no significant difference in the survival of termites in the two bioassays $(F=1.40 ; d f=1,8 ; P=0.27)$. At Day 14 , all the replicates of both tests had $\geq 89 \%$ survival.

In Colony Pair KL, there was no significant interaction between bioassay design and time period $(F=1.40$; $d f=1,56 ; P=0.23)$. There was no significant difference in the percent survival of termites in the two bioassays $(F=0.21 ; d f=1,56 ; P=0.64)$. There was a highly significant difference in percent survival at the different time periods $(F=4.6 ; d f=1,56 ; P=0.001)$. Survival of 

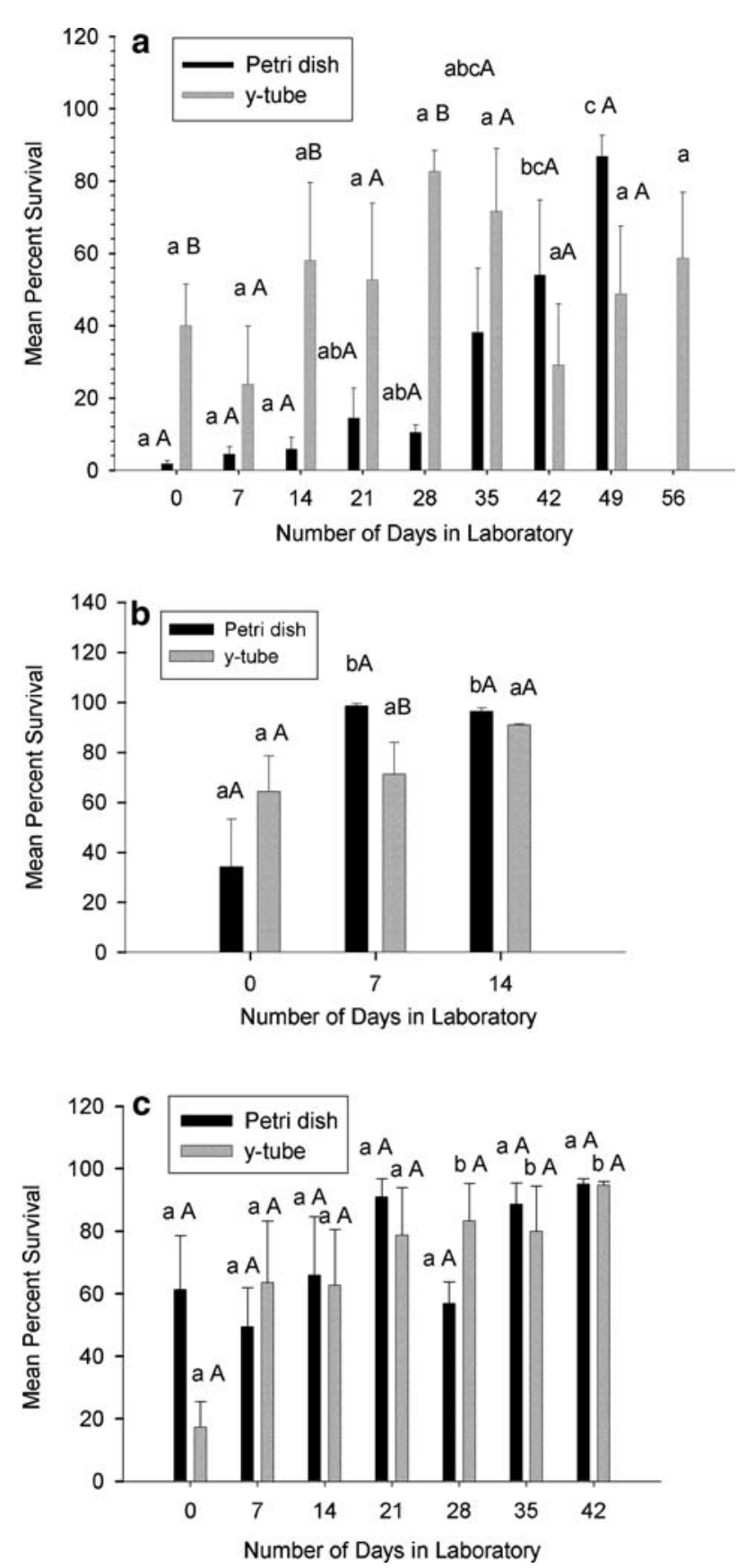

Fig. 2 Mean $( \pm S E M)$ percent survival of termites in colony pairs in 72-H Petri dish and 72-H y-tube tests. Percent survival of termites in bars with the same lowercase letters within a bioassay (Petri dish or $y$-tube) was not significantly different on the different days. Percent survival of termites in bars with the same uppercase letters within a time period was not significantly different in the two bioassays. a BD, b GM, c KL

termites at Day 0 was significantly lower than survival at Days 28, 35, and 42 in the $72-\mathrm{H}$ y-tube tests (Fig. 2c). Survival of termites in $72-\mathrm{H}$ Petri dish tests was not significantly different at the different time periods, but survival varied widely between replicates in the same time period. For instance, at Day 0, survival in the five replicates of the $72-\mathrm{H}$ Petri dish test ranged from 93 to $2 \%$. After 42 days, all of the replicates in both tests had $\geq 88 \%$ survival (Fig. 2c).

\section{Discussion}

The rapid loss of agonism in groups of termites kept in the laboratory demonstrates that changes in environmental factors affect intercolonial agonism. However, the laboratory diet of the termites had no effect on termite survival in any of the bioassays. Because $C$. formosanus colonies forage at multiple sites, the diet of the colony is probably comprised of cellulose obtained from multiple sources. It is possible that loss of contact with the colony could cause rapid changes in the composition of gut symbiotic microorganisms due to the restriction to one food type in the laboratory. These dietary restrictions may have played a role in the loss of intercolonial agonism. The presence of colony-specific gut microbiota may play a role in nestmate recognition (Dropkin, 1946; Matsuura, 2001; Minkley et al., 2006). Wei et al. (2007) were able to induce aggressive behavior among workers from the same colony that were treated with different antibiotics, demonstrating that changes in the composition of the gut microbial community can induce aggressive behavior in C. formosanus.

There was a great deal of variability among replicates within the same test concerning whether termites engaged in combat. There was generally either evidence of widespread fighting and a high degree of mortality within a particular replicate or very low mortality and no evidence of fighting within a particular replicate. In other studies, observations of marked workers revealed that only one or a few members within a small group actually displayed aggressive behavior toward other colony members for both C. formosanus (Cornelius and Osbrink, 2003) and Reticulitermes spp. (Polizzi and Forschler, 1999; Delphia et al., 2003). Delphia et al. (2003) suggested that aggressive behavior initiated by only one or a few individuals within a group triggers the release of chemical and/or behavioral cues that cause increased aggression in the rest of the group.

Because of the high degree of variability in aggressive behavior exhibited by $C$. formosanus individuals, agonism tests using small, isolated groups of foragers may not adequately reflect colony behavior in the field, regardless of bioassay design. However, studies with other termite species have found that laboratory bioassays predict aggressive interactions in the field. In a study of aggression in the termite, Nasutitermes corniger (Motschulsky), bioassays were conducted with small groups of workers and soldiers 
in Petri dishes to assess levels of agonistic behavior. In order to test whether these Petri dish bioassays could predict aggressive behavior in the field, nests were transplanted in the field to locations in proximity to nests of other colonies. In the field, workers and soldiers from two colonies that were not agonistic in laboratory bioassays joined together without fighting, but workers and soldiers from colonies that were agonistic in laboratory bioassays engaged in intense fighting. Hence, for $N$. corniger, results of Petri dish bioassays with small groups of termites were correlated with colony behavior in the field (Adams et al., 2007). In addition, in agonism tests conducted using three termite species, Nasutitermes princeps (Desneux), N. novarumhebridarum ( $\mathrm{N}$ and $\mathrm{K}$ Holmgren), and Microcerotermes biroi (Desneux), results from laboratory bioassays were consistent with bioassays conducted in semi-natural conditions (Leponce et al., 1996).

In concurrence with findings of other researchers ( $\mathrm{Su}$ and Haverty, 1991; Shelton and Grace, 1997; Messenger and $\mathrm{Su}, 2005 \mathrm{a}$ ), bioassays with field-collected termites demonstrated that some colony pairs engaged in intense combat, while other colony pairs exhibited no evidence of agonism at all. In some cases, levels of aggression were very high among neighboring colonies. Colony $\mathrm{B}$, the colony with the greatest number of interactions with other colonies that resulted in a significant reduction in survival, shared a contiguous border (traps located $<50 \mathrm{~m}$ apart) with two other $C$. formosanus colonies (Colonies A and D) (Cornelius et al., 2007). Survival of termites from pairings of Colony B with A and D were 6 and $4 \%$, respectively.

Field studies of Formosan subterranean termites demonstrate that colonies maintain relatively stable boundaries for at least several years (Messenger and Su, 2005b; Messenger et al., 2005; Cornelius et al., 2007). Although there is some evidence from a field study that colony fusion may have occurred in C. formosanus ( $\mathrm{Su}$ and Scheffrahn, 1988), there is no genetic evidence of colony fusion (Husseneder et al., 2005; Vargo et al., 2006). However, there is evidence that colony fusion occurs in populations of R. flavipes, R. grassei, and R. banyulensis (Clément and Bagnères, 1998, Clément et al., 2001; DeHeer and Vargo, 2004, 2008; Nobre et al., 2008).

It has been proposed that colony fusion can be an adaptive tactic where colonies accept or reject conspecific intruders depending on the cost and benefit of colony fusion and that the relative nymph ratio of the host colony and the introduced colony is a key factor in determining the level of intercolonial agonism (Matsuura and Nishida, 2001). DeHeer and Vargo (2008) have suggested that an unknown maternally inherited factor may cause colony fusion in Reticulitermes.
Because $C$. formosanus colonies maintain distinct foraging territories and frequently act aggressively towards members of neighboring colonies, survival of isolated groups of foragers that get separated from the colony would likely be low. However, in the absence of agonism, these isolated groups of foragers could be absorbed by other colonies. Orphaned foragers that have become separated from the colony may be able to survive through absorption into a healthy, functioning colony. Absorption of small, orphaned groups of workers and soldiers of $C$. formosanus into another colony may be advantageous for both the intruders and the host colony.

Acknowledgments We would like to thank Leanne Duplessis, Erin Lathrop, and Mark Lovisa for their invaluable technical assistance. We would like to thank Debbie Boykin for her assistance with the statistical analysis. We would also like to thank Beverly Wiltz for her helpful comments on an earlier version of this manuscript.

Open Access This article is distributed under the terms of the Creative Commons Attribution Noncommercial License which permits any noncommercial use, distribution, and reproduction in any medium, provided the original author(s) and source are credited.

\section{References}

Adams E.S., Atkinson L. and Bulmer M.S. 2007. Relatedness, recognition errors, and colony fusion in the termite Nasutitermes corniger. Behav. Ecol. Sociobiol. 61: 1195-1201

Austin J.W., Szalanski A.L., Scheffrahn R.H., Messenger M.T., Dronnet S. and Bagnères A.-G. 2005. Genetic evidence for the synonymy of two Reticulitermes species: Reticulitermes flavipes and Reticulitermes santonensis. Ann. Entomol. Soc. Am. 98: 395-401

Bouillon A. 1970. Termites of the Ethiopian region. In: Biology of Termites, vol. 2. (Krishna K. and Weesner F.M., Eds). Academic Press, New York, pp 153-280

Bulmer M.S. and Traniello J.F.A. 2002. Lack of aggression and spatial association of colony members in Reticulitermes flavipes. J. Insect Behav. 15: 121-126

Clément J.-L. and Bagnères A.-G. 1998. Nestmate recognition in termites. In: Pheromone Communication in Social Insects: Ants, Wasps, Bees, and Termites (Vander Meer R.K., Breed M.D., Espelie K.E. and Winston M.L., Eds). Westview Press, Boulder, Colorado. pp 126-155

Clément J.-L., Bagnères A.-G., Uva P., Wilfert L., Quintana A., Reinhard J. and Dronnet S. 2001. Biosystematics of Reticulitermes termites in Europe: morphological, chemical and molecular data. Insect. Soc. 48: 202-215

Cornelius M.L. and Osbrink W.L.A. 2003. Agonistic interactions between colonies of the Formosan subterranean termite (Isoptera: Rhinotermitidae) in New Orleans, Louisiana. Environ. Entomol. 32: 1002-1009

Cornelius M.L., Duplessis L.M. and Osbrink W.L.A. 2007. The impact of Hurricane Katrina on the distribution of subterranean termites (Isoptera: Rhinotermitidae) in City Park, New Orleans, Louisana. Sociobiology 50: 311-335

DeHeer C.J. and Vargo E.L. 2004. Colony genetic organization and colony fusion in the termite Reticulitermes flavipes as revealed 
by foraging patterns over time and space. Mol. Ecol. 13: 431441

DeHeer C.J. and Vargo E.L. 2008. Strong mitochondrial DNA similarity but low relatedness at microsatellite loci among families within fused colonies of the termite Reticulitermes flavipes. Insect. Soc. 55: 190-199

Delphia C.M., Copren K.A. and Haverty M.I. 2003. Agonistic behavior between individual worker termites from three cuticular hydrocarbon phenotypes of Reticulitermes (Isoptera: Rhinotermitidae) from northern California. Ann. Entomol. Soc. Am. 96: 585-593

Dronnet S., Lohou C., Christides J.-P. and Bagnères A.-G. 2006. Cuticular hydrocarbon composition reflects genetic relationship among colonies of the introduced termite Reticulitermes santonensis Feytaud. J. Chem. Ecol. 32: 1027-1042

Dropkin V.H. 1946. The use of mixed colonies of termites in the study of host-symbiont relations. J. Parasitol. 32: 247-251

Florane C.B, Bland J.M., Husseneder C. and Raina A.K. 2004. Dietmediated inter-colonial aggression in the Formosan subterranean termite. J. Chem. Ecol. 30: 2559

Getty G.M., Haverty M.I. and Lewis V.R. 2000. Agonistic behavior between recently collected and laboratory cultured Reticulitermes spp. (Isoptera: Rhinotermitidae). Pan-Pac. Entomol. 76: 243-250

He H., Mo, J. Pan, C. and Zhang, S. 2005. Intercolony agonism and protein variation based on environmental cues in Coptotermes formosanus (Isoptera: Rhinotermitidae). Sociobiology 46: 615625

He, H.Y., Mo J.C., Teng L., Pan C.Y., Zhang C.X. and Cheng J.A. 2006. No influence of exocrine glands on nestmate discrimination in Coptotermes formosanus (Isoptera: Rhinotermitidae). Sociobiology 47: 253-264

Husseneder C. and Grace J.K. 2001. Evaluation of DNA fingerprinting, aggression tests, and morphometry as tools for colony delineation of the Formosan subterranean termite. J. Insect Behav. 14: 173-186

Husseneder C., Grace J.K., Messenger M.T., Vargo E.L. and Su N.-Y. 2003. Describing the spatial and social organization of Formosan subterranean termite colonies in Armstrong Park, New Orleans. Sociobiology 41: 61-65

Husseneder C., Messenger M.T., Su N.-Y., Grace J.K. and Vargo E.L. 2005. Colony social organization and population genetic structure of an introduced population of Formosan subterranean termite from New Orleans, Louisiana. J. Econ. Entomol. 98: $1421-1434$

Leponce M., Roisin Y. and Pasteels J.M. 1996. Intraspecific interactions in a community of arboreal nesting termites (Isoptera: Rhinotermitidae). J. Insect Behav. 9: 799-817

Matsuura K. 2001. Nestmate recognition mediated by intestinal bacteria in a termite, Reticulitermes speratus. Oikos 92: 20-26

Matsuura K. and Nishida T. 2001. Colony fusion in a termite: what makes the society "open"? Insect. Soc. 48: 378-383

Messenger M.T. and Su N.-Y. 2005a. Agonistic behavior between colonies of the Formosan subterranean termite (Isoptera: Rhinotermitidae) from Louis Armstrong Park, New Orleans, Louisiana. Sociobiology 45: 331-345

Messenger M.T, and Su. N.-Y. 2005b. Colony characteristics and seasonal activity of the Formosan subterranean termite (Isoptera: Rhinotermitidae) in Louis Armstrong Park, New Orleans, Louisiana. J. Entomol. Sci. 40: 268-279
Messenger M.T., Su N.-Y., Husseneder C. and Grace J.K. 2005. Elimination and reinvasion studies with Coptotermes formosanus (Isoptera: Rhinotermitidae) in Louisiana. J. Econ. Entomol. 98: $916-929$

Minkley N., Fujita A. Brune A. and Kirchner W.H. 2006. Nest specificity of the bacterial community in termite guts (Hodotermes mossambicus). Insect. Soc. 53: 339-344

Nobre T., Nunes L., Bignell D.E. 2008. Colony interactions in Reticulitermes grassei population assessed by molecular genetic methods. Insect. Soc. 55: 66-73

Pan C., Mo J. and Cheng M. 2006a. Influence of diet and soil on intercolonial aggression of Coptotermes formosanus (Isoptera: Rhinotermitidae). Sociobiology 48: 841-848

Pan C., Mo J., Chen C., Cheng C.M. and Cheng J. 2006b. Difference of trace elements is not a factor inducing intercolony aggression in Coptotermes formosanus (Isoptera: Rhinotermitidae). Sociobiology 48: 155-164

Polizzi J.M. and Forschler B.T. 1999. Factors that affect aggression among theworker caste of Reticulitermes spp. subterranean termites (Isoptera: Rhinotermitidae). J. Insect Behav. 12: 133-146

Shelton T.G. and Grace J.K. 1996. Review of agonistic behaviors in the Isoptera. Sociobiology 28: 155-176

Shelton T.G. and Grace J.K. 1997. Suggestion of an environmental influence on intercolony agonism of Formosan subterranean termites (Isoptera: Rhinotermitidae). Environ. Entomol. 26: 632637

Su N.-Y. and Haverty M.I. 1991. Agonistic behavior among colonies of the Formosan subterranean termite, Coptotermes formosanus Shiraki (Isoptera: Rhinotermitidae), from Florida and Hawaii: Lack of correlation with cuticular hydrocarbon composition. J. Insect Behav. 4: 115-128

Su N.-Y. and Scheffrahn R H. 1988. Foraging population and territory of the Formosan subterranean termite (Isoptera: Rhinotermitidae) in an urban environment. Sociobiology 14: 353-359

Su N.-Y. and Tamashiro M. (1987). An overview of the Formosan subterranean termite (Isoptera: Rhinotermitidae) in the world. In: Biology and Control of the Formosan Subterranean Termite (Tamashiro M. and Su N.-Y., Eds). College of Tropical Agriculture and Human Resources, University of Hawaii, Honolulu, HI, pp 3-15

Thorne B.L. and Haverty M.I. 1991. A review of intracolony, intraspecific, and interspecific agonism in termites. Sociobiology 19: $115-145$

Uva P., Clément J.-L. and Bagnères A.-G. 2004. Colonial and geographic variations agonistic behaviour, cuticular hydrocarbons and mtDNA of Italian populations of Reticulitermes lucifugus (Isoptera, Rhinotermitidae). Insect. Soc. 51: 163-170

Vargo E.L., Husseneder C., Woodson D., Waldvogel M.G. and Grace J.K. 2006. Genetic analysis of colony and population structure of three introduced populations of the Formosan subterranean termite (Isoptera: Rhinotermitidae) in the continental United States. Environ. Entomol. 35: 151-166

Wei J., Mo J., Pan C., Deng T., Cheng M. and Chen C. 2007. The intestinal microbes inducing the agonistic behavior of intercolonial individuals in Coptotermes formosanus (Isoptera: Rhinotermitidae). Sociobiology 50: 245-256

Zhang S., Mo J., Teng L., Cheng M. and Cheng J. 2006. Inter-colonial variation in the composition of the frontal gland secretion of Coptotermes formosanus (Isoptera: Rhinotermitidae). Sociobiology 47: $553-561$ 